\title{
Voluntary Military Organizations, Associational Life and Urban Culture in Early Modern England
}

The voluntary military organizations that blossomed in English towns and cities in the first half of the seventeenth century constitute one of the most fascinating yet also one of the most elusive of historical phenomena. Their importance seems obvious - as a focus of military and political enthusiasm in a century of civil war, and also as associations potentially informed by militant religious sentiments. Their significance as organized, armed bodies of men meant that they could play a potentially decisive role in the politics of the 1630 s and $1640 \mathrm{~s}$, and we know that successive governments showed an anxiety either to nourish them, or later, to seize their arsenals, while they also provided training grounds for some military figures of national importance. They nevertheless remain surprisingly little studied.

The elusiveness of these companies is in some respects easily explained by the relative dearth of pertinent surviving materials, particularly their own records. But this also means that they have been dealt with in very limited ways, either slotted into the history of English military development, or featuring briefly in high political narratives (the London Artillery Company in particular has a short walk-on part in the period preceding the Civil War). ${ }^{1}$ Yet historians have very little sense of what these companies were actually doing most of the time - why they were formed, who joined them, what purposes they served, what activities they pursued, or how these changed over time. A whole series of assumptions are made about their political and religious agendas based on limited evidence, while by default their role beyond acting as conduits of military education has largely remained unexplored.

This article seeks fundamentally to rethink the phenomenon of voluntary military organizations and adopts a fresh perspective on their activities, drawing upon new and revealing evidence. It will argue that they can supply an important missing element in the broader history of associational life in the early modern period. Historians have tended to place the origins of modern voluntary associations in the post-Restoration period, among the clubs and societies that generally met in taverns, inns and alehouses. ${ }^{2}$ But this study argues that pre-war voluntary military associations were important and hitherto neglected precursors of these social phenomena. A unique set of company accounts for the period up to 1639 , and other scattered surviving materials, make one specific voluntary military organization -- the Military Company in Westminster -- easily the best documented company of this period. This makes it possible to piece together a coherent account of its organization and activities (in contrast to its better known but sparsely documented counterpart, the London Artillery Company). ${ }^{3}$ These unique sources enable us to combine literary evidence with analysis of the social practices and material culture of a voluntary military organization. This article also explores the neglected spatial characteristics of these associations (with their private yards, use of communal space or in some cases, physical premises), which could play an important role in an evolving process of

\footnotetext{
${ }^{1}$ Boynton, Elizabethan Militia; Donagan, "Halcyon Days and the Literature of War "; Lawrence, The Complete Soldier, especially 1-15; Geldof, "The Pike and the Printing Press," 149ff; Hunt, "Civic Chivalry and the English Civil War," 231-4; Adamson, Noble Revolt, 65-70; Pearl, London and the Outbreak of the Puritan Revolution, 171-5, 188, 278-9; Ashton, City and Court, 173-6. Prak has studied formal civic militias in early modern Europe within the context of state formation. Despite their declining military role with the rise of professional soldiering by the seventeenth century, he notes that they continued to play an important role in early modern town life and (given their link to civic government), could foster 'citizen agency': Prak, "Citizens", 119-123.

${ }^{2}$ Clark, British Clubs and Societies; Withington, "Company and Sociability"; Barry, "Bourgeois Collectivism? Urban Association and the Middling Sort"; Withington also traces the usage in print of terms employed to conceptualize forms of association in the seventeenth century, see Withington, Society in Early Modern England, especially 113-22.

${ }^{3}$ No accounts or minutes survive for the Artillery Company for the pre-War period and other provincial companies would appear not to have left institutional records.
} 
identity formation. We are thus able to place the company in its proper context, not simply as an episodically militant radical group, but as a form of urban association.

Voluntary military organizations developed in later sixteenth and early seventeenth-century England, in the wake of war with Catholic Spain, and in response to specific military conflicts abroad or a perceived military threat at home. That being said, a taste for martial imagery and language was more widespread in the Elizabethan and early Stuart period. Although often linked to particular concerns over continental warfare, it was a broader strand running through English cultural life: military drilling could be a popular recreation combining 'manly' exercise and patriotism, while complementing Renaissance and gentry notions of chivalry and valour. Active enthusiasm may have waxed and waned, but military activity was always a significant element in the construction of masculinity, Protestant patriotism and aristocratic culture. ${ }^{4}$

A key feature of these organizations was their overtly voluntary nature, and the apparently independent initiatives behind their formation. Peter Clark has commented that before the civil war there were only a very few voluntary associations that "functioned in a public way" and these did so under the umbrella of existing, formal institutions, such as the Society of Antiquaries and the College of Heralds. ${ }^{5}$ The military companies, however, suggest a more varied picture for the pre-war period. There was a flurry of petitions to the Privy Council in the Jacobean period to set up military companies, coming from a range of towns, including Norwich, Bristol, Gloucester, Coventry, Ipswich and Great Yarmouth. ${ }^{6}$ These petitions often invoke the example of the most familiar military society in early modern England -- the London Artillery Company -- an organization loosely connected to the pre-Reformation Guild of St George, which was revived under Elizabeth and then again under James I. But the Artillery Company was untypical of these other military companies in ways that also help explain its larger profile, not least the fact that London's lord mayor and aldermen were directly involved in its government and funding, as was the Crown. ${ }^{7}$ Its public image was deeply intertwined with that of the City of London, as evidenced by the poem commissioned in 1622 at the completion of its Armoury, which tellingly portrays the project as emerging from London's citizenry, from the "Aldermen's Love" ("their Grant and our Request together met") and from the City's special link to the Crown. ${ }^{8}$ It made sense for aspiring companies to invoke the Artillery Company's example to reassure the Crown of the orderly and respectable character of the intended organization, given that

\footnotetext{
${ }^{4}$ Pearl, London and the Outbreak of the Puritan Revolution, 172; Donagan, "Halcyon Days,", 100; Howes, The Annales (1615), 936; Mulryne, “"Here's Unfortunate Revels”,'167-70; Keen, Chivalry, 219; Sherlock, "Militant Masculinity."

${ }^{5}$ Clark, British Clubs and Societies, 48.

${ }^{6}$ Norwich and Bristol in 1625, Gloucester and Great Yarmouth in 1626; Coventry (1628) and Ipswich (1629): CSPD 1625-6, 131, 326, 333; APC 1619-21, 406-7; APC 1621-3, 344; APC 1625-26, 211, 309, 464, 477; APC 1627-8, 30; TNA, PC/2/39, fos. 207, 446; Boynton, Elizabethan Militia, 262-64; Roberts, Great Yarmouths exercise, title page. Boynton (Elizabethan Militia, 264) notes these petitions, but was clearly unsure as to their character, and therefore simply refers to them as petitions to 'institute yards', a tendency that has continued in subsequent work. His account of the Military Company (215-16) partly conflates it with the Artillery Company while there are no relevant sources given to support his assertion of the Military Company's link to Prince Henry and Prince Charles (see below, note 15).

${ }^{7}$ London's Court of Aldermen appointed the chief officers and paid the professional soldiers who trained members of the Society, although these arrangements were frequently disputed. The Privy Council reinstated the captain, Thomas Panton, in 1619, when the Company dismissed him without consultation, since as the Council noted, he had been placed there by their authority: Pearl, London and the Outbreak of the Puritan Revolution, 170-73; Raikes, Ancient Vellum, 4; Raikes, History, I, 51.

${ }^{8}$ The lord mayor and aldermen were always invited to the Company feast, which was partly funded by the Corporation from at least 1620: Raikes, History, I, 56.
} 
these societies involved the creation of a body of armed men, not formally embedded within local government. Thus a petition of 1621 in support from the bailiffs and aldermen of Colchester reassured the king that only those whose "lives, Conversacions \& Religion" were fitting and approved by the bailiffs of the town would be permitted to gather under their "worthie" Captain. ${ }^{9}$ But while the involvement of local governors might be promised, the initiative did not necessarily come from them. In the case of Norwich, for example, the petition was sent by the citizens and inhabitants of Norwich. It cited the "worthie example" of the "citty of London in the Artillerie Yarde", but it was the petitioners who promised to ensure that the members and actions of the organization received the approbation of the lord mayor and aldermen. ${ }^{10}$

There is a danger, therefore, in simply categorizing all these organizations as mere extensions of the county militia or trained bands. ${ }^{11}$ These were in many ways hybrid organizations, with varying relations to town corporations. ${ }^{12}$ What seems clear, though, is that they all (including the Artillery Company) contained a significant voluntary element. This voluntary element was also often reflected in the companies' fluctuating membership levels and fortunes.

This pattern is best evidenced by the Military Company in Westminster because here there was no town corporation to be associated with in the first place. Instead, the town of Westminster lay in an area of the capital that fell outside the jurisdiction of the powerful City of London. For this reason, a tradition of informal, ad hoc government by parish notables had developed in the medieval period. By the early modern period, this lack of corporate government was increasingly anomalous, given the huge increase in building and population that overtook the area-but once again, local parishioners from the town's main parishes simply found ways of acting collectively in the absence of the sort of executive government found in London. ${ }^{13}$ This history of adaptation, informal association and jurisdictional independence helps to explain the creation of a separate military company for the area, as we shall see (and that the company also attracted members from adjacent parishes of the western suburbs). ${ }^{14}$ The one major institution that loomed over Westminster was the royal court itself, but the enduring claim that the Company was founded by Prince Henry must be discounted. Not only is there no proper evidence for this story (which seems to date from the late seventeenth century, informed by some confusion and nostalgia for the militarily-minded young prince), but there is specific evidence against it. ${ }^{15}$ Even if the martial character and connections of Henry's court at St James's Palace might

\footnotetext{
${ }^{9}$ TNA, SP14/121, f. 217. Bailiffs seem to be senior governing officials, as in Great Yarmouth, where they filled the role played by mayors in other towns: Tittler, Townspeople and Nation, 226.

${ }^{10}$ APC 1623-25, 482 (23 Feb 1624/5).

${ }^{11}$ Voluntary associations and these bodies might sometimes co-operate closely -- as in the case of the Artillery Company and the London Trained Bands -- but they remained distinct entities: Raikes, History, I, 102; Ashton, City and Court, 173, 175-6. There is a separate historiography on the Elizabethan and early Stuart militia, but this tends to focus on the difficulty of maintaining and reforming them and their relations with central government: for a useful summary see Braddick, State Formation in Early Modern England 1550-1700, 190-96. Later seventeenth-century York has been the subject of a rare cultural study by P. Withington, "Citizens, Soldiers and Urban Culture in Restoration England."

${ }^{12}$ In the capital there were also some smaller suburban companies, such as 'Townsditch' and 'Cripplegate' (Elton, The Compleat Body of the Art Military, 67), and Southwark (Chestlin, Persecutio Undecima, 56).

${ }^{13}$ Merritt, Social World, 353-5.

14 Those behind the petition to create the Company (APC 1615-16, 360-1) are described as being from "the Cititie of Westminster, St Martins in the Fieldes, St Clement Danes, the Savoy, [St Andrew] Holborne and St Giles in the Field's" and this remained its core membership.

${ }^{15}$ Kingsford, Early History, 57-8, notes John Bagford's erroneous history of the site, dating from the early eighteenth century (in British Library, Harleian MS 5900, f. 45) which asserted that "Prince Henry caused a piece of ground near Leicester Fields to be walled in for the exercise of arms". Despite the fact that the ground was not acquired until after Henry's death, Bagford claimed it was a place "he much delighted in". Much scholarship, generally following Boynton, Elizabethan Militia, 215, still repeats this red herring: Gregg, King
} 
have helped to spark local interest in military activities, the creation of the Military Company was independent of royal involvement and is documented in a petition sent to the Privy Council in December 1615 (three years after Henry's death) seeking its approbation. ${ }^{16}$ Once the Military Company had received the Council's approval, an order sent by the Council to the Commissioners of Musters in Middlesex placed great emphasis upon the company's voluntary character, referring to the group of "manie sufficient and honest inhabitaunts" from the area who had been given permission to be trained "at their owne charge". The Council further recommended Captain Thomas Holcroft as a person suitable to instruct the men, who were said to include some already enrolled with the Middlesex trained bands, but also "others whoe beinge furnished with good armes, are fitt to bee exercised in the use and practize thereof'. ${ }^{17}$ The strong voluntary element within the organization is also confirmed in an order of the Council to Holcroft, referring to his instruction of these "voluntaries" who "come weekly" (despite some squabbling with the lieutenants of Middlesex over Holfcroft's authority). ${ }^{18}$ And once again, a Council order of 1617 emphasized its desire to give "all favour and assistance", particularly given that "the exercise is meere voluntary, and proceedeth only from their owne readines and dispocision", and noting their "greate charge" in purchasing a ground to practice, and in fitting themselves with "faire and serviceable armes, to the strength and advantage of theis partes upon all occasions". Later in the same year the Council gave the company permission to choose its own captain (after the death of Holcroft), provided that he was presented to the Council for approval. ${ }^{19}$

The structure and character of voluntary military organizations has proved very difficult to reconstruct, given the sparse nature of surviving information (even the London Artillery Company lacks proper institutional records before 1658). However, the Military Company in Westminster is again a rare exception, as the survival of its accounts provides invaluable insights into the organization. The sophistication of the body is evident almost from the beginning and suggests that those behind it were men with other organizational and financial experience, or that they pooled the experience of members from various spheres. Accounts were kept from the beginning (draft accounts 1616-1626/7), while a previously unknown, fair account book now sheds light on the period 16221639 (albeit with some gaps). ${ }^{20}$ The size of the Company is difficult to determine at any one time, since although the accounts recorded new members (who paid an 'entrance' fee of 10s), there are no membership lists that survive for any one year, nor do the accounts note when members died or simply stopped paying their yearly quarterage fee. ${ }^{21}$ As the Artillery Company (which drew members

Charles I, 30; Manning, An Apprenticeship in Arms, p. 144; Lawrence, Complete Soldier, 127; Bennett, Cardew Rendle Roll, 29.

${ }^{16}$ APC 1615-16, 60-1. While Charles I was later alluded to as a patron of the Company (Taylor, Valew of true valour, 20), there is little evidence of significant involvement or that he imitated the style of military engagement that characterized Prince Henry: Lawrence, Complete Soldier, 129-30.

${ }^{17}$ APC 1615-16, 361 (italics mine). The Company paid Sir Clement Edmondes, clerk of the Privy Council (and a St Martin's parishioner), to promote their petitions: TNA, SP16/88/35, f. 69v. For his military interests: Thrush and Ferris, House of Commons 1604-1629, s.n. Clement Edmondes; Aylmer, The King 's Servants, 133. ${ }^{18}$ APC 1616-17, 302.

${ }^{19}$ APC 1616-17, 415.

${ }^{20}$ The Company accounts that survive in Queen's College, Oxford [QCO], although a fair copy and highly informative, are not entirely consistent in what they record beyond the entrance fees of new members and the wages of Company employees. Information about food and drink and specific weapons and armoury is not fully itemised, and it seems likely that donations from members also supplied some of the Company's needs. 'Extraordinary' expenditure on building tends to be more fully documented, but yearly quarterage payments were evidently recorded in separate accounts that do not survive.

${ }^{21}$ The entrance fee of 10 s remained the same from the 1610s to the end of the 1630s, cf. TNA, SP/16/35, f. 72 and QCO, MS 77, f. 41. Lack of membership lists means we cannot measure the impact of events such as the plague epidemic of 1625 and the lesser outbreak of 1636. 
from the City and some from the suburbs) was prevented by the Crown from recruiting more than 500 members, one assumes the Military Company never exceeded this number and it is likely to have been smaller, given that it drew on a smaller geographical area. ${ }^{22}$ Approximately 136 men joined the Military Company during a membership surge around June/July 1635, while the number of tickets printed for a feast the year before would suggest a prior membership of at least 250 (so perhaps a total membership of at least 386 in mid-1635). ${ }^{23}$ This means that members of both companies represented only a small fraction of the capital's residents. ${ }^{24}$ Nevertheless, both the Artillery Company and the Military Company had a profile and significance disproportionate to these relatively small numbers.

More generally, surviving accounts flesh out our picture of the Company in other ways. For example, for some years the enrolment of new members includes the street or parish where the member lived and occasionally his occupation. Key figures in the company were the treasurers (who managed the company's finances and whose role was akin to that of churchwardens), the Captain (who was paid, rather than serving in a voluntary capacity), and by at least 1633-34, a "President", along with the "Especiall assembly", which seems to have been elected. ${ }^{25}$ By the 1630s, eight men were paid yearly by the company, including the "captain", a "serjeant", a clerk, drummers and fife-players, an armourer and a porter, who served as a general factotum. The Company's activities included weekly drilling, a yearly feast with music, and some more elaborate joint exercises with the London Artillery Company. These more public occasions could attract large numbers: 550 tickets were issued for an event in 1634-5. This event accompanied the "fetching" of the company's ordnance from the Tower of London, while 400 tickets "more" were issued for the "feast", which presumably included guests. ${ }^{26}$ Unlike the Artillery Company, the Military Company purchased its own ground, and quickly built an armoury on part of the property. By the 1630s, it had also erected a fine two-storey brick building that served as a meeting place for its members. ${ }^{27}$

The Military Company accounts also shed valuable light on the social complexion of those who joined the company. Despite the area's proximity to the Court, it did not attract titled members, and those identified as gentlemen were a minority. The company may have received some aristocratic encouragement, but the only specific example dates from 1623, at the height of concerns over the Spanish Match, when the 'patriot' earl of Southampton allowed the grounds of Southampton House (in St Andrew Holborn) to serve as the venue for one of the company's formal exercises, which was accompanied by music and dancing. ${ }^{28}$ Otherwise it is unclear whether members of the peerage

\footnotetext{
${ }^{22}$ Raikes, History, I, 43-4. I have not been able to find evidence documenting a cap for the Military Company, which is not to say that it did not have one.

23 QCO, MS 77, fos. 26, 27-29v.

${ }^{24}$ Thus, St Martin in the Fields, a single one of the enormous and increasingly expanding parishes of Westminster, had 853 ratepayers (not residents) in 1631: WAC, F358a. See also Merritt, Social World, 260-62. I would like to thank Jeremy Boulton for access to the dataset created for his work on paupers in St Martin in the Fields.

${ }^{25}$ Although treasurers are identified consistently in the accounts, the President was not. The first recorded President was George Hulbert in 1633, who was a treasurer in 1628-9, a Westminster JP and member of the Westminster Court of Burgesses and of the Vintners' Company. He later clashed with the earl of Bedford: QCO, MS 77, fos. 8, 23; Merritt, "Creation of the Parish of St Paul Covent Garden," 46-7.

${ }^{26}$ QCO, MS 77, fos. 33v-34.

${ }^{27}$ By contrast, the Artillery Company was given permission to exercise on land belonging to the Crown, which led to clashes over its use. The Company only obtained a secure tenure over their premises by securing a lease for part of Bunhill Fields in 1641 from the City, transferring most of their activities to this new site: Survey, Spitalfields and Mile End New Town, 24-7.

${ }^{28}$ QCO, MS 77, f. 2v. Beyond the crisis of the Spanish Match, no evidence has emerged to suggest that aristocrats acted as company patrons for specifically political reasons or that it was targeted by aristocrats as a
} 
attended the Company feasts, while their names do not appear among those donating to company projects, such as the rebuilding of the Armoury in 1633-34. ${ }^{29}$ Similarly, there is little indication that the company was seen as a focus for aristocratic chivalric expression and in that sense, its training (of adults, not youths) contrasts with that provided briefly (1635-6) by the Museum Minervae in nearby Covent Garden, with its ambition to act as an academy for the nobility and its demands for proof of gentility from its prospective students. ${ }^{30}$

Most Military Company members came from the middling sort. ${ }^{31}$ The fee for joining was a substantial 10 s, with a yearly quarterage fee payable thereafter. The amount of the quarterage fee is impossible to determine precisely since fees were collected by squadron and only sporadically listed in the surviving accounts, and then only as lump sums. It is unlikely to have been less than $4 \mathrm{~s}$ per annum, similar to the $4 \mathrm{~s} 4 \mathrm{~d}$ that was most commonly levied for the poor rate in St Martin in the Fields. The company was thus most likely to have been affordable for those of householder status. ${ }^{32}$ But who were the members of the Military Company? Most numerous were tailors (very common), vintners, brewers, chandlers, cutlers, and carpenters and joiners. More generally, though, it is clear that members of the Military Company conformed to the occupational patterns of the Westminster parishes and adjacent parishes of the western suburbs, encompassing those servicing the developing West End, Inns of Court, royal courts of justice and the royal court at Whitehall. For this reason we find those associated with the building trades, clothing (tailors, shoemakers, drapers, milliners), food and drink (those supplying the area's many inns and taverns, plus bakers and poulterers), while more specialist occupations such as booksellers, artists, goldsmiths, watchmakers, silkmen and perfumers, who catered to a more elite clientele, also appear among the Company's membership. Residency information also reveals a small but significant minority of professional men associated with the Inns of Court or minor government bureaucrats, some of whom could claim gentlemanly status. ${ }^{33}$ More members seem to be given the title "esq." or "gent." in listings for 1638-9, although they are still a minority. ${ }^{34}$ More generally, though, it seems likely that the Military Company facilitated social

vehicle for political puritanism on the eve of the Civil War (this is suggested by Adamson in relation to the earl of Warwick and the Artillery Company in 1640: Adamson, Noble Revolt, 68-9).

${ }^{29}$ However on two occasions in the 1630s, the Company accounts refer to brief contact with peers of quite different political stripes. In 1635 they returned banners to the earl of Warwick's house at Leighs Priory, Essex (the puritan earl had a house in Holborn, social and commercial links with parliamentary puritans in the City and was involved in attempts to reform the militia in Essex: QCO, MS 77, f. 37; Pearl, London and the Outbreak of the Puritan Revolution, 229; Lawrence, Complete Solider, 209). The payment may refer to a joint exercise with the Artillery Company. The pro-peace earl of Portland gave the company some wine in 1633-34 (f. 24), but the circumstances are unclear, and the offering reminds us that aristocrats routinely were called upon to perform a military role in their localities. Portland himself, for example, was joint Lord Lieutenant with Warwick and sole Lord Lieutenant of Hampshire and Captain of the Isle of Wight in the early 1630s despite his cryptoCatholicism: Thrush and Ferris, House of Commons 1604-1629, s.n. Richard Weston; Boynton, Elizabethan Militia, 265.

${ }^{30}$ For the Museum Minervae, see Survey, Covent Garden, 255-58; Cust, "Charles I's Noble Academy."

${ }^{31}$ Occupations are only recorded sporadically until the account of 1638-39, while some evidence from the wills and churchwardens' accounts has also been used to supplement this material: see Merritt, Social World, passim.

${ }^{32}$ QCO, MS 77, f. 12 refers to the collection of quarterage fees by squadron, while f. 14v. notes monies collected by six men for quarterage fees in 1631-32, totalling c. £56. The rough calculation of a 4s quarterage fee is based on an assumption of 250 members, the number of tickets printed for a feast in 1633-1634 (f. 26), with the poor rate figured derived from WAC, F358a.

${ }^{33}$ QCO, MS 77, fos. 41-43.

${ }^{34}$ The use of titles is problematic, though, as Company records tended to refer to members collectively as 'gentlemen' or to give the title of 'Mr' in the lists of those joining or donating monies for Company projects. Those taking leases from Westminster Abbey often describe themselves as 'gentlemen', even though we know from other sources that they practised occupations such as brewers and linen drapers: Merritt, Social World, 125. 
interaction between the prosperous middling sort and gentlemen via its shared, public purpose, which makes it all the more appropriate to categorise it with later voluntary societies. ${ }^{35}$

It does not appear that the Military Company was dominated by those from particular parishes or their office-holding elites. While it is possible to identify parish officials from some of the Westminster parishes these do not seem to represent those who served most regularly in office together or who served in the highest tiers of parish government. It seems, therefore, that the Military Company did not act as a simple extension of parochial identity. For example, a long-simmering dispute over the Company's use of lammas lands in St Martin in the Fields erupted when the parish vestry ordered a mass assertion of its rights in May 1618, which forced the captain and members of the Company to acknowledge parochial rights when summoned to a vestry meeting five days later. ${ }^{36}$

These findings all have important implications for understanding the cultural life of the Military Company. But first we must consider the aspect of the voluntary military organizations best known to historians: their connection to political puritanism. Here the Military Company again offers a more intriguing and nuanced picture than is often implied. Company sermons were linked to their yearly feast on St James's Day (25 July) - a date presumably chosen in compliment to the king. Two sermons preached to the company were published in 1618 and 1629 respectively. ${ }^{37}$ These sermons shed important light on the motives and levels of the support for the company during a period of warfare and shifting alliances on the continent and disagreement at home over England's foreign policy, and repay detailed study.

By 1618, not many years after the creation of the company, threats to continental Protestantism and the outbreak of the Thirty Year's War made the importance of English military training seem more important than ever. ${ }^{38}$ The choice of the strongly puritan John Everard, parish lecturer at St Martin in the Fields, to preach to the Company in 1618 is particularly striking. In the years that followed, Everard was one of the most outspoken opponents of a royal foreign policy involving a marriage between the Spanish Infanta and the Prince of Wales, and he was periodically imprisoned for his sermons attacking marriage with Catholic "idolaters". ${ }^{39}$ His sermon to the Military Company took place on 25 July 1618, in connection with their annual feast, and therefore only months after the start of the Thirty Years War in May. The outbreak of hostilities would seem to be suggested by the vehemence of the published sermon, which went beyond general platitudes about the value of military preparedness. ${ }^{40}$ Despite alterations to the published version (presumably to delete explicit attacks) ${ }^{41}$ it nevertheless still contains a good deal of thinly-veiled criticism of crown policy. ${ }^{42}$ It paints a vivid picture of the international threats that England faces and the need for military preparedness based on examples drawn from history. It also contains a sustained critique of those who naively privilege

\footnotetext{
${ }^{35}$ Note that the Artillery Society was said to attract both citizens and gentlemen: Ashton, City and Court, 173.

${ }^{36}$ WAC, F2001, fos. 112, 117a, 121, 121a.

${ }^{37}$ Everard, Arriereban and Taylor, Valew; QCO, MS 77, f. 13v.

${ }^{38}$ Donagan, "Halcyon", 74, 76, 81; Lawrence, Complete Soldier.

${ }^{39}$ St Martin's vestry provided financial support during his periods of imprisonment: Merritt, Social World, 336, 338-9, 342, 345; ODNB, s.n. John Everard.

${ }^{40}$ Lawrence, Complete Soldier, pp. 76, 203, 225, 230.

${ }^{41}$ The sermon was delivered at St Andrew Holborn, not far from the company's ground in St Martin's Field. Everard pointedly laments the alterations and that "the liberty of the Pulpit is too little, but that of the Presse, in our affaires, is much lesse": Everard, Arriereban, Dedication to the company and its captain.

${ }^{42}$ Eg. Everard, Arriereban, 60, 87-8, 99-100.
} 
peace, despite the danger of the times, with many scholarly quotations and examples cited at length. ${ }^{43}$ Everard also specifically praises the Company as a voluntary organization, whose efforts are all the more noteworthy and to be distinguished from the behaviour of those "in publique places of trust", adding darkly of them "may he that gaue them the dignity endue them with abilitie to performe it." By contrast, he lauds "you, beloued, who to this purpose bring euery man his own selfe, and that Willingly...[God] shall giue victory to you". ${ }^{44}$

Not surprisingly, Everard praises the "nurceries" of the Artillery Company and the Military Company, whom he brackets together. But he also notes their opponents, who either mocked as pointless the newly-built wall that the Military Company had erected to enclose its yard or suggested that "this warlike humour is an incentive to Rebellion". The publication of the sermon undoubtedly raised the Company's profile, and aligned it with political puritanism, but Everard was careful not to paint himself (or indeed members of the company, by implication) as seditious, and his exposition was laced with classical allusions just as much as biblical ones. ${ }^{45}$

The 1618 sermon by Everard ultimately praises the company for the example that it sets, which is depicted as robust and well-positioned to support a godly foreign policy of the sort that was increasingly invoked in parliament and elsewhere by the early 1620s. By contrast, the sermon delivered in July 1629 by Thomas Taylor and subsequently published with the Company's encouragement that year addresses a very different military situation in the wake of the dissolution of parliament in March 1629. This clearly marked the end of English involvement in the Thirty Years War and the Stuarts' effective abandonment of the international Protestant cause, as peace treaties were negotiated with France and Spain. ${ }^{46}$

Taylor's dedication explains that he was asked by the company to publish his sermon - which is striking given that the sermon, entitled The Valew of True Valour, provides something of a public critique of the company. The need to revitalize the Military Company via a godly agenda is Taylor's main theme. Unlike Everard, Taylor was a City of London minster (not from one of the local parishes) and his choice as preacher would have stemmed from godly networks among members of the company - presumably the same people who seem to have informed him of company affairs. He notes the "jarres and quarrels" within the company, which he has "heard" have almost overthrown bonds of love and unity. More specifically, he also alludes to the low turn-out for exercises and the decline of the company and its reputation. ${ }^{47}$

Taylor praises the Military Company as a society that is specifically voluntary in character, but this points to its potential weakness: "it were pitty that that which should be the glory of [y]our action, (I meane the freenesse of it) should become the ouerthrow of it." 48 Significantly, what emerges indirectly from Taylor's account is that those who had joined in the 1610s and 1620s represented a wider constituency than just pro-war puritans. And indeed, the non-godly element may actually have increased over time. Taylor discusses the true qualities of a soldier, but also warns that the company should not be dishonoured by swaggering, swearing, drinking or indeed failure to attend the weekly exercises. ${ }^{49}$ His position as a critical friend of the Company prompts him to add "wee are more willing

\footnotetext{
${ }^{43}$ Everard, Arriereban, 29, 55-6.

${ }^{44}$ Everard, Arriereban, 60-61.

${ }^{45}$ Everard, Arriereban, 32.

${ }^{46}$ Questier, Dynastic Politics and the British Reformations, 452-4.

47 Taylor, Valew, 23 ("Yea my selfe haue beene an eye witnesse of your slender appearance").

48 Taylor, Valew, 24.

49 Taylor, Valew, 21.
} 
to behold a seemely appearance in your exercises marching vnder your colours in the field: then to see you marching to a feast". ${ }^{50}$ Taylor's solution to the Company's problems is a very specific one. To improve, he stresses the need to "get into your company men that feare God; the more of them you can draw in; the more happy and flourishing will your company be. Such as these will intend the publicke, and not their private ends: their vertuous life will cast a lustre vpon your meetings, their religious speeches and godly counsels will tend to edification". ${ }^{51}$ Taylor goes on to make some practical suggestions, including fines for members who fail to attend meetings, something the company appears to have implemented. ${ }^{52}$

We do not know the causes driving the "jarres and quarrels" within the Military Company, alluded to by Taylor. A strongly shared religious motivation may have united members of voluntary military organizations in times of crisis, but outside such periods, other factors, including social competition or local disputes may also have weighed heavily. We may assume, though, that it was the godly element within the Military Company which orchestrated this very public attack on their opponents among its membership. Taylor's sermon, then, provides us with a more nuanced view of the role of religion in voluntary military companies. Rather than simply functioning as religiously homogenous vehicles of militant godly activism, companies could reflect a more unstable alliance between its members' diverse social and religious motives and aspirations. For the many non-godly company members (and perhaps for some of the godly too), "marching in the field" and "marching to a feast" were not necessarily the behavioural opposites that Taylor portrayed and there may often have been painful and acrimonious debates over company activities.

Despite Taylor's pessimism regarding the Company's fortunes, it nevertheless seems to have found a second wind by around 1633, when a number of new initiatives (including building works) galvanized the company, and numbers of members rose again starting in the mid-1630s. Although judging the exact number of members at any one time is not possible, the accounts do list the 'entrances' of new members for most the period, which enables us to chart two surges in membership. One in 1635 (which can be paralleled with the Artillery Company, which had experienced a similar decline in its membership in the early 1630s) coincides with important international events. A treaty between the Protestant German princes and the Emperor Ferdinand II drew attention to the weakness of continental Protestantism, and particularly the plight of the Elector Palatine, who was specifically excluded from the amnesty. This year also witnessed the entry of France into the war to combat the ambitions of Spain, a fact widely reported in England, where there was renewed hope that the country might intervene once more in the conflict. ${ }^{53}$ The surge in Company membership mostly occurred in June and July, the months immediately following the Treaty of Prague. No fewer than 136 men joined in these two months and included some who 'having formerly been ancient members of the Said society' had paid to join again. ${ }^{54}$ The next surge in membership was in March 1639, which coincided with war against the Scots (the First Bishops' War) and the first sustained military mobilization of the decade, albeit this time against a Protestant neighbour. This internal threat encouraged a variety of new members including a sprinkling of gentry. They ranged from Sir Charles Gawdy (a member of

\footnotetext{
50 Taylor, Valew, 21-2.

51 Taylor, Valew, 25-7.

52 Taylor, Valew, 23; QCO, MS 77, f. 24.

${ }^{53}$ Sharpe, Personal Rule, 509-15; Raikes, Ancient Vellum, 43-5.

${ }^{54}$ QCO, MS 77, fos. 27-29v. Those re-joining were John Harris, Samuel ‘Barndo’ and Jeremy Kellett (f. 29v), for whom see also below. This pattern of increased membership around 1635 also seems to have been experienced by the Artillery Company, which once again reflects a sensitivity to the international situation and the Palatinate cause: Raikes, Ancient Vellum, 46-52.
} 
the royal household, but with puritan inclinations) ${ }^{55}$ to the courtier Sir Endmyion Porter. ${ }^{56}$ While most were not gentry and lists still reflect the earlier mix of occupations, the accounts do list slightly more new members who are described as 'gentlemen' or 'esquire' and more who were from the Inns of Court. ${ }^{57}$ This would tally with a political environment in which the Crown, eager to fight the war without calling Parliament, leaned on those with court connections to provide voluntary donations and may account for more new members from the Inns of Court. ${ }^{58}$ This membership surge of March 1639 was not replicated by the Artillery Company, though, and the significant puritan element within the Artillery Company are likely to have been more sympathetic to the cause of the Scottish Covenanters. ${ }^{59}$ As a result of recruitment to the Military Company in 1639, its puritan membership is likely to have been diluted, and the social and political profile of the association may also have altered.

Nevertheless, it should be emphasized that membership in military organizations in the 1620s and 1630s is not a straightforward predictor of civil war allegiance. In the case of the Military Company, the parliamentarian Richard Elton drew attention to the excellent military training he received from its Captain, the professional soldier Henry Tillier, although Tillier himself became a royalist major general. Similarly, Valerie Pearl has observed that the records of the Artillery Company 'do not show it was entirely the preserve of the future supporters of Parliament, and particularly after the crown's interference in the Company [in 1630] few parliamentary puritans enrolled'. Nevertheless, after 1639, when freedom of elections was restored, parliamentary puritans in the company did consolidate their position and take office ${ }^{60}$ In the event, the Military Company would find itself summoned to play a role in its own backyard during the so-called 'December days' of popular tumults in 1641 - an extension of policing duties which it had occasionally been called upon to perform from back in the $1620 \mathrm{~s} .{ }^{61}$ During the civil war itself its resources would be deployed in a number of ways, which will be discussed briefly below.

III

One reason why political puritanism was not necessarily the only voice in voluntary military organizations is that, at least in the case of the Military Company, the company also performed multiple other functions. And this brings us to a larger point - the neglected role of military companies in the broader history of voluntary associations. As we have already noted, these tend to be presented as a facet of the post-Restoration world, while few pre-war associations functioned in a public fashion, and operated only under the umbrella of existing formal institutions. Yet the Military Company did not emerge from an existing institutional link, and although it modelled itself on the Artillery Company in terms of military training, it also drew upon a variety of other sources of inspiration. Moreover, its cultural identity was not set in stone but changed and developed over time.

It is important at the outset to note that the Military Company was based in the vicinity of several venues that served as what we might term experiments in public sociability. As I have discussed elsewhere, venues such as Spring Gardens (near Charing Cross) and Shaver's Hall (in Leicester Fields) were popular new venues in the early Stuart period. They operated as early forms of pleasure

\footnotetext{
${ }^{55}$ QCO, MS 77, f. 41v; Thrush and Ferris, House of Commons, s.n. Sir Charles Gawdy II (1st baronet).

${ }^{56} \mathrm{QCO}, \mathrm{MS} 77, \mathrm{f} .43$. The precise month of Porter's 'entrance' is not clear.

${ }^{57} \mathrm{QCO}, \mathrm{MS} 77$, fos. 41-43v.

${ }^{58}$ Hibbard, Charles I and the Popish Plot, chs. 5-6.

59 Raikes, Ancient Vellum, pp. 55-7; Bennett, Cardew Rendle Roll.

${ }^{60}$ Elton, Compleat Body, 67; Pearl, London and the Outbreak of the Puritan Revolution, 172; Chestlin, Persecutio Undecima, 56.

${ }^{61}$ Merritt, Westminster 1640-60, 42. See in relation to Shrove Tuesday in 1626, APC 1625-1626, 347.
} 
grounds that overtly appealed to a sense of exclusivity and fashionable taste, but clearly attracted prosperous members of the urban middling sort as well as those of higher status. ${ }^{62}$ This was a partly over-lapping clientele that emerged in this period, of the sort who also flocked to the luxury shops in the New Exchange (built in 1609) in the Strand, and to the fashionable new housing of the West End, particularly the planned development of Covent Garden. The Military Company was obviously not a commercial organization, but a corporate one, with a very public agenda. Nevertheless, it also seems to have shaped itself in ways that reflect some of these newer forms of taste and sociability and it can and should be seen as one - albeit neglected -- part of the development of the West End. ${ }^{63}$

Discussion of the culture of the Military Company as an urban association should begin with its chief symbol as a corporate body: its private premises. There has been a tendency among historians to discuss military companies in terms of the 'yard' where they drilled, which contemporaries sometimes used as shorthand to refer to the company itself. But this runs the risk of too literal a reading, to the exclusion of the members themselves and the other activities in which they engaged and the buildings which they occupied. Although the Military Company possessed an armoury and an enclosed ground from early in its history, the erection of the Military House in fields north of Charing Cross provides us with telling insights into two key facets of the Company. ${ }^{64}$ The first is the way in which the building and its furnishings reflected the most fashionable tastes of the 1620s and 1630s, with implications for the diffusion of these markers of high status, as we can also partly see in the nearby planned development of Covent Garden. Secondly, the building's configuration and furnishings also testimony to a vigorous campaign to manufacture a corporate identity for the organization and to facilitate certain forms of sociability. ${ }^{65}$

We may begin with the theme of fashionability. The erection of what came to be called the Military House, in 1633-34 onwards, resulted in a two-storeyed brick building with two wings (also incorporating a new room acting as an armoury). The prompt to expand may well have come from a fire at the old armoury, a building that itself had earlier attracted considerable expense, with its stone "mantletree" moved to this new property. ${ }^{66}$ What is particularly notable about the 1630 s expenditure, though, is that it housed comprehensively under one roof a number of the company's functions, beyond just the storing of arms. The building included a "fair chamber" called the Assembly room, a "spacious" room described as the Armoury, other smaller chambers, a kitchen, and (perhaps most striking of all) a library ${ }^{67}$ The creation of this bespoke accommodation was carried out by the most fashionable craftsmen working in early modern England, some of whom were actually members of the company. This involved expensive stonework and handsome interior fittings. Even before the 1630s expenditure, those holding the Company purse-strings had evinced a taste for high-status items of the sort normally associated with the houses of aristocrats and royalty. Around 1626, the noted sculptor and master mason, Nicholas Stone, was paid 46s for a sun dial for the company. This follows the model of the famous sun dials created by Stone a few years previously for several properties in the locality, namely St James's Palace (c. 1619), the King's Privy Garden at Whitehall (1622) and Brooke House in Holborn (1622), the house of Fulke Greville, Lord Brooke. These were all examples that would have been well known not only as unusual decorative items, but ones of scientific interest, with

\footnotetext{
${ }^{62}$ Merritt, Social World, 164-7, 171, 196; Survey, St Martin in the Fields, pt. III, 58-9, for the further development of Spring Gardens in the Jacobean period.

${ }^{63}$ Merritt, Social World, 164-7, 171, 196.

${ }^{64}$ See details of acquisition of the property in Survey, St Anne Soho, 380-84, 431.

${ }^{65}$ For the development of fashionable society in the West End, see Merritt, Social World, chapter 5; Merritt, "Creation of St Paul Covent Garden."

${ }^{66}$ In 1633-34, QCO, MS 77, fos. 23-23v.

${ }^{67}$ This description mostly follows a Parliamentary survey of 1652 (see Kingsford, Early History, 59-60), TNA, C5/486/26, but also the terminology used in the accounts.
} 
the Privy Garden dial credited to Edmund Gunter, Gresham Professor of Astronomy. ${ }^{68}$ And even in its earlier building, which had also hosted meetings of the 'especial assembly', the Company had installed expensive painted glass, clearly showing that the building was much more than a mere storage facility. ${ }^{69}$

More generally, members of the Company included leading craftsmen, some of whom were also regularly employed by the King's Works, or who worked on the new development of Covent Garden and its fashionable new church of St Paul's, designed by Inigo Jones. This partly reflected the fact that many members of the building trades and the King's Works lived in the western suburbs, including Stone himself, who served as overseer of the poor at St Martin in the Fields. Other craftsmen who worked on the Military House were also members of the Company. These included Jeremy Kellett (an upmarket joiner who supplied the pulpit, reader's desk and many of the pews at St Paul's and was a friend of the mason Stone) ${ }^{70}$ the carpenter Richard Ryder (who was paid for work on the Armoury and also worked extensively on many of the major building projects of the West End), and the plasterer, Cleophas Hearne. ${ }^{71}$ The company also attracted other men who would have been aware of the latest cultural tastes, such as the "limner", David "Degranne" of Blackfriars, who joined in $1635,{ }^{72}$ and Edmund Kinsman, a master mason active in the King's Works, who was paid $£ 5$ for the stonework of the "great dore" and "one dore case of Portland stone" at the Military House, but was also employed by Inigo Jones for projects, including the new front of St Paul's Cathedral . ${ }^{73}$

The building works that took place in the 1630s, primarily in 1633-34, resulted in an interior with features such as two fine stone fireplaces, Portland stone door cases, and the royal arms, as well as items of curiosity, such as a "great Tortoise shell" (an echo of the cabinets of curiosities associated more with grand private houses). ${ }^{74}$ We have seen how the period around the First Bishops' War (1639) may have prompted greater numbers of gentlemen to join the company and here they would doubtless have found premises already to their taste. It is perhaps in this context that some of the acquisitions of the period need to be seen, with increased expenditure on furnishings for the library (discussed below). Work undertaken towards the feast of 1639 brought improvements to the Armoury and the library, while $£ 13$ was paid to the painter Nicholas Harger (a recent warden of the Painter Stainers Company, and company member since 1626) and 30s paid for "heads of plaister" for the Armoury', which may be the "Statues of Emperors heads" referred to in a later inventory. ${ }^{75}$

An especially significant and striking aspect of the Military House was the creation of a library. There were very few institutional libraries in the capital in the early Stuart period, beyond the royal libraries, or those associated with religious institutions or the Inns of Court. The Military Company library therefore represents an important and hitherto unknown example in the history of libraries and book

${ }^{68}$ QCO, MS 77, f. 5; Spiers, ed. Note-Book... of Nicholas Stone, 49; Gunter, The Description and Use of Dials in Whitehall Garden, Epistle Dedicatory, which explains it astronomical uses.

${ }^{69}$ A Mr. Leigh had been paid $£ 2$ 1s. 6d. for a window in the armoury in 1618: TNA, SP16/88/35, f. 72; QCO, MS 77, f. 3.

70 QCO, MS 77, f. 29v; Survey, Covent Garden, 41. Kellett was also a picture-frame maker producing a frame for an enormous landscape of London by George Portman, for William Paston at Oxnead Hall in Norfolk: Spiers, Note-book ...of Nicholas Stone, 96-7, 158.

${ }^{71}$ Ryder joined around the same time as his work on the Armoury (1633-34): QCO, MS 77, fos. 23, 24v. For Hearne, see f. 28. Both men worked on Covent Garden church: Survey: Covent Garden, 271-4. Ryder also undertook carpentry work for a pastoral and masque performed by Henrietta Maria at Somerset House in 1633: Cerasano and Wynne-Davies, eds. Renaissance Drama by Women, 170.

72 QCO, MS 77, fos. 35v-36, 1635-6. "De Granne" must be David des Grange, the Protestant, Anglo-French miniaturist, who moved shortly thereafter to Covent Garden: $O D N B$, s.n. David des Granges.

${ }^{73}$ Colvin, Ransome and Summerson, eds. History of the King's Works, III, pt. 1, 148, 150-51, IV, 329; QCO, MS 77, f. 23.

${ }^{74}$ QCO, MS 77, fos. 23-23v, 44 (c. 1638-9).

${ }^{75}$ QCO MS 77, fos. 6v, 43, 44v; Pitman, Worshipful Company of the Painters, 54; TNA, C5/486/26. 
collecting. A library designated as a room (rather than a collection of books) was also very rare in this period, although library rooms were to be found in the Strand at Northumberland House and Salisbury House in the 1610s. ${ }^{76}$ The Military Company library, however, inhabited a cultural context that was different to both grand houses and to institutions more explicitly dedicated to scholarship. By housing books in a location where they would be accessible to those involved in military training, the Military Company library effectively answered a broader call among military writers of the period to bring together theory and practice, and it would undoubtedly have contained works of classical history, as many of these were deemed pertinent to the study of warfare. ${ }^{77}$ The library also draws attention to another function of the House -- as a place of study. It is not clear exactly when the library was created, but presumably this was during the more substantial building work of the mid-1630s. Payments in 1638-39 include "whiting" the library, "coloring the boxes" and the purchase of a new desk. The very modern addition of a library clearly lent prestige to the Company, and it sometimes served as the backdrop to sociable activities - as suggested by the payments for sack and claret provided "in the library", courtesy of some of the more prominent members. ${ }^{78}$

The internal furnishings of the Military House also demonstrate efforts being made to manufacture a distinctive identity for the Military Company as a corporate body, something that was facilitated through the material culture it generated. The decision to purchase 48 red leather chairs, for example, reflects the elevated status of certain members within the Company. It also suggests that these seats were likely to have been for a smaller decision-making body ${ }^{79}$ possibly the elusive "especial Assembly" referred to in company accounts from at least the first half of the $1620 \mathrm{~s} .{ }^{80}$ The building also contained a large press and drawers "wherein were kept the rolls \& writings belonging to the Company" ${ }^{81}$ A sense of corporate unity was also recognized through the display of a benefactors board, while gifts to the Company were generally highlighted or decorated within the fair copy of the Company accounts. The use of terms such as the 'gentlemen' of the Company also lent its members a shared dignity and exclusivity. Referring to members as 'gentlemen' was a trend observable in some other military companies too, and William Barriffe's Military Discipline of 1635 refers to "the Gentlemen of the private and loving Societie of the Cripplegate Meeting". The term "society" for the association only occasionally appears in the Military Company manuscript accounts, however, although Withington has shown that as the century progressed, the term "society" (with more elite connotations) was beginning to overtake the place of "company" in printed contexts. ${ }^{82}$

\footnotetext{
${ }^{76}$ Pearson, "English Private Library in the Seventeenth Century", 386.

77 Geldof, "The Pike and the Printing Press", 148. Bagford claimed that the house contained "a well-furnished Library of all such books as related to arms, chivalry, military affairs, encamping, fortifications et. that best that could be got in that kind in all languages", and although his account of the Company may not be reliable, his comments may reflect a memory of the library among antiquarians: Kingsford, Early History, 61.

${ }^{78}$ QCO, MS 77, fos. 43v-44. Few livery company halls had what were termed libraries before the Restoration, beyond the Apothecaries (in competition with the Royal College of Physicians) and the Stationers Company. I would like to thank Anya Matthews Lucas and David Pearson for discussing these issues with me. See also Matthews, 'Bibliotecture: The Design of the Seventeenth Century English Library', 4.

${ }^{79}$ TNA, C5/486/26. See accounts of 1631-32 for purchase of a carpet for "ye assembly Table", an hour-glass and a stand for writing implements, QCO, MS 77, f. 16v.

${ }^{80}$ QCO, MS 77, f. 2v.

${ }^{81}$ TNA, C5/486/26.

${ }^{82}$ Barriffe, "Military Discipline”, 'To the Worthy Captaines Edward Dichfield and Henry Sanders'; eg. QCO, MS 77, fos. 17, 29v; Withington, Society in Early Modern England, 105. Sermons addressed to the Artillery Company also tended to 'ennoble' company members: Hunt, "Civic Chivalry", 223.
} 
Feasting was also an important feature of the Company's corporate life. Feasts involved considerable expenditure and were a key element in identity-formation among other bodies in the capital, such as livery companies, which did not operate in suburban areas such as Westminster. ${ }^{83}$ The Company's annual feast in July was plainly the highlight of the year, to which guests were invited. But it is also notable that the new Military House included a purpose-built kitchen. ${ }^{84}$ Members were clearly not content to rely on socialising in commercial premises, such as inns or taverns, which sometimes had substantial private rooms within what were public spaces and were utilised for a range of purposes, including meetings of parish officers. The kitchen also allowed the company to offer private dining to its members, but perhaps more importantly, to guests, although the big feast days would clearly not have been reliant on this single kitchen. Although the bigger livery companies tended to have kitchens for their feasts and entertaining, the provision of kitchens was also a response to the requirements of fashionable leisure in the period, such as the pleasure gardens of Shaver's Hall and Spring Gardensplaces that allowed some social mixing, albeit with an aura of exclusivity, and which combined public and private aspects. ${ }^{85}$

Drilling together and the shared discipline it entailed through regular meetings presumably were also key to the development of a corporate sense, and it seems likely that this military model—of chains of command but also of interdependence -- was an attraction for members, as was the 'manly exercise' that was traditionally associated with military companies. But there were other processions and elaborate formal exercises, based around the Company's annual feast in July. On these occasions the members were addressed collectively as a body in the sermons that were delivered, while the occasion demanded that members were garbed in distinctive (and colourful) military attire and armed with weapons that were sometimes borrowed especially for the occasion. Their involvement in processions also meant that they were observed by spectators as part of this corporate entity with their banners and ensigns - something significant to beholder and beheld. ${ }^{86}$

Although few public occasions other than the annual feast are recorded by the Company, one exception that emerges from the accounts came in 1632, when the Company paid for 200 tickets for "warning" company members to attend the funeral of the brewer Joseph Bradshaw. Bradshaw was not only a fellow member but had been elected MP for the town of Westminster in 1628, when electors rejected a proposed 'court' candidate in favour of local men, such as Bradshaw. Members attended the funeral itself, supplying a dozen torches, where it is likely that a prominent puritan minister would have delivered the sermon, given the godly tendencies of Bradshaw and members of his family. ${ }^{87}$

Some Company activities went beyond expressions of comradeship, godly or otherwise, but were clearly part of a campaign for public recognition of the Military Company as something comparable to London's Artillery Company. This came when the company received a coat of arms some time around 1638/9. The "fetching home" of the arms was an expensive and elaborate event held over several days, probably including a procession from London (possibly from the College of Arms), giving money to poor prisoners of Ludgate and Newgate along the way, a grand dinner involving the

\footnotetext{
${ }^{83}$ Archer, Pursuit of Stability, 116-20; Kilburn-Toppin, "'Discords have arisen and brotherly love decreased'," 28-38. Nevertheless, some residents did in suburban areas did belong to the London companies.

${ }^{84}$ QCO, MS 77, f. 31v.

${ }^{85}$ Merritt, Social World, 164-6, 196, 171; The Artillery Company, by contrast, negotiated use of the Armourers' Company kitchen and hall for their feast and assemblies on a yearly basis in 1612, although by 1620 their feast was held at the Merchant Taylors' hall, Raikes, History, I, 40-41, 56; Raikes, Ancient Vellum, xvi. ${ }^{86}$ QCO, MS 77, fos. 2v, 5v, 6v, 25v, 31-31v, 33-33v, 44-44v.

${ }^{87}$ QCO, MS 77, 1632-33, f. 21; For his 'entrance' see f. 6v. Joseph was the son of the godly John Bradshaw, for whom see especially Merritt, Social World, 323; Thrush and Ferris, House of Commons 1604-1629, s.n. Joseph Bradshaw.
} 
heralds, and payments to the King's Trumpeters. It was preceded by lavish preparations well in advance, including more building work, inside and out. The event may also have coincided with the Company's annual feast. ${ }^{88}$ The acquisition of a coat of arms was a public statement about the Company and its anticipated longevity and status. It was also an occasion that boosted shared bonds of affiliation and presented a united front to the world.

The Military Company also seems to have occasionally collaborated with the Artillery Company in larger scale military exercises on the outskirts of the capital (such as Hyde Park and St James's Park and possibly Finsbury Fields), which provided a form of martial entertainment, sometimes with members of the royal family in attendance. ${ }^{89}$ The site owned by the Military Company, as we have seen, was originally obtained to provide a ground for drilling and although a house was built on one part of the property, members also performed their weekly exercises here. The exercises accompanying the yearly feast, in particular, would have had a strongly theatrical aspect to them. By the end of the 1630s, the Company paid for a series of different tickets to mark particular occasions, including "ordinary" and "special" tickets, plus tickets to mark the king's birthday, ${ }^{90}$ which suggests substantial numbers of spectators. ${ }^{91}$ Given the number involved, it is not surprising that James Shirley's West End-based play The Lady of Pleasure (c. 1635) also shows an awareness of the Company, with one of the female characters declaring playfully that "we'll feast the parish in the field, and teach/The military men new discipline". ${ }^{92}$

Discussion of the theatrical aspects of military performance should not of course be allowed to detract from the Company's serious military potential. For these occasions, the company erected various temporary buildings (a "fort" is mentioned in 1627), while we have more details about structures created for the later 1630s, which included a mini-fortress, protected by a drawbridge, with "spikes and tenterhooks" about the bridge, all designed to practice the various aspects of warfare. ${ }^{93}$

IV

The military potential of the voluntary companies was to be readily exploited in the years that followed. As I have discussed elsewhere, the Military Company did indeed play a military role by the 1640s and its ordnance was real enough to be requisitioned when war broke out, while some of the Company's members became captains in the local regiments in the ensuing hostilities. ${ }^{94}$ In addition, in May 1647 Parliament offered a generous settlement to the Company to cover war damage in what

${ }^{88}$ QCO, MS 77, fos. 43v-44v.

${ }^{89}$ QCO, MS 77, fos. 21, 25v, 37-37v, 44v.

${ }^{90} \mathrm{Eg}$. QCO, MS 77, f. 37r-v; 44v.

${ }^{91}$ Ordinary and special tickets around 1638-9: QCO, MS 77, f. 43v. Four hundred tickets were printed "for the feast" in July 1635 and 500 tickets at the same time for "fetching home the ordinance" (f. 31v). This may suggest large number of observers, since only 260 tickets were printed to elect a new assembly in the same year's account (but the election may have taken place before the 1635 surge, which brought in around 150 men).

${ }^{92}$ Shirley, The Lady of Pleasure, 70.

${ }^{93}$ QCO, MS 77, fos. $43 \mathrm{v}-44$.

${ }^{94}$ Journals of the House of Commons, 11 Feb. 1643. Company members who became captains in the Westminster forces include Thomas Constable (prominent in local Westminster government in the 1650s) and Michael Barkstead, an officer in the Trained Bands, who nevertheless signed the Westminster Peace Petition, Merritt, Westminster 1640-60, 54, 139. 
was clearly an attempt to gain the support of independent military forces in the capital for defence against the disgruntled army. ${ }^{95}$

By the 1650s it appears that the Company's military role was probably suspended, yet its social role in the locality survived in ways that might not have been predicted. And here its relatively remote location in fields on the outskirts of the capital may be relevant, for the Military House became the venue for the covert performance of plays (at least from c. 1656/7), a banned activity at the time, as well as one new opera. ${ }^{96}$ In this the choice of the Military House is significant for two reasons. The first seems to be that by agreeing to allow such banned activities, it served as a venue for cultural tastes that ran counter to the governments of the day, with their emphasis on moral reform and sabbatarianism. It may well have also attracted royalist sympathizers, helped by its location outside the built-up areas of the capital. In addition, the building itself was particularly well suited to the combination of activities that theatrical entrepreneurs sought in a performance space. We have little to document the Company's activities after this, although its petition to be granted "liberty for the exercise of their Armes" in their grounds was granted by the reinstated Rump on 31 May 1659, after the fall of Richard Cromwell. ${ }^{97}$

The Restoration marked the nadir of the Company's fortunes, but this seems to have partly been down to simple bad luck. Clearly those who remained members were seen as sufficiently loyal to the new regime that the Company continued to operate, and it was said that they gained the patronage of Charles II's younger brother, the Duke of Gloucester, but he died only months after the Restoration. Thereafter the Company may have lacked powerful protectors, for it found itself enmeshed in a series of lawsuits with the ruthless Charles Gerrard, a former royalist officer and colonel of the First Troop of Horse Guards, who challenged the title to their property and ultimately used soldiers under his command to enter the house, despoiling the interior, destroying valuable books and objects, and smashing the painted glass windows. The Company never really recovered, and its property ultimately did come into Gerrard's hands. Its desirable West End location meant that it was sold to the famous speculator, Nicholas Barbon, who built houses for profit, including one occupied by Gerrard himself. ${ }^{98}$ More fundamentally, this fortuitous dissolution led to the erasing of the Company and its history from the story of the emergent West End, of which it could have been a distinctive feature.

As we have seen, voluntary military organizations were potentially far more than a simple side-show of military development, or companies with an occasional walk-on part in national politics. They must undoubtedly have had very diverse characteristics and changing functions. Nevertheless, the example of the Military Company demonstrates that they also had the potential to become active participants in the changing social and cultural developments of the Jacobean and early Caroline period. They were also distinctive in terms of their voluntary characteristics and the manner in which members related to one another and in this way were precursors of later associational developments. Members of military companies, whatever precisely prompted them to join, were necessarily linked together by participation in shared activity - military exercise and training — while their membership and rationale was not based around a shared occupation. By contrast, members of livery companies, one of the most prominent urban associations of this period, met in order to regulate and promote their craft, and their meetings were not structured around an activity. The focus of military companies on an activity, then, makes them closer in character to some of the clubs emerging in the eighteenth century. Military companies also bear some similarities to the voluntary charitable organizations that emerged in this later period, with a public agenda pursued via (largely) voluntary private means. Their role in social

\footnotetext{
95 Journals of the House of Lords, 28 May 1647; Merritt, Westminster 1640-60, 64.

${ }^{96}$ Randall, Winter Fruit, 45, 133; Jeaffreson, ed. Middlesex County Records, vol. 3, 189; WAC, F385 (1657-58).

${ }^{97}$ Merritt, Westminster 1640-60, pp. 215-17; Bodleian Library, Rawlinson MS C.179, p. 33.

${ }^{98}$ Survey, St Anne Soho, 380-84; Kingsford, Early History, 60.
} 
and cultural history has thus been seriously neglected. Clearly, military companies had the potential to be many different things, and governments, corporations and individuals alike may have sought to deploy and direct them in different ways, but it is only by combining all aspects of these multi-faceted organizations that we can recapture the role that they played. They hence supply a vivid but hitherto neglected dimension to our picture of the social and cultural life of early modern England.

\section{Bibliography}

\section{Manuscript Sources}

Bodleian Library, Rawlinson MS C.179

Matthews, Anya. "Bibliotecture: The Design of the Seventeenth Century English Library" MA thesis, King's College London, 2011.

TNA, C5/486/26

TNA, PC/2/39

TNA, SP14/121

Queens College, Oxford, MS 77

Westminster Archives Centre, F2001

Westminster Archives Centre, F358a, F385

\section{Contemporary Published Sources}

Barriffe, William. Military Discipline or the Yong Artillery Man. London, 1635.

Chestlin, Thomas. Persecutio Undecima. London, 1648.

Elton, Richard. The Compleat Body of the Art Military. London, 1650.

Everard, John. The Arriereban: A Sermon Preached to the Company of the Military Yarde. London, 1618.

Gunter, Edmund. The Description and Use of His Majesties Dials in Whitehall Garden. London, 1624.

Howes, Edmund. The Annales, or a Generall Chronicle of England. London, 1615.

Roberts, John. Great Yarmouths Exercise. In a Very Compleat and Martiall Manner Performed by Their Artillery Men. London, 1638.

Taylor, Thomas. The Valew of True Valour, or, the Probation and Approbation of a Right Military Man Discovered in a Sermon Preached July 25. Before the Worthy Gentlemen of the Military Company. London, 1629

\section{Printed Calendars and Primary Sources}

Acts of the Privy Council [APC] Volumes 35, 37, 38, 39, 43 (1616-1628), edited by J.V. Lyle, London: HMSO, 1927-1940.

Calendar of State Papers Domestic [CSPD]: Charles I, 1625-26, edited by John Bruce, London: HMSO, 1858.

Journals of the House of Commons: Volume 2 (1640-1643) London: HMSO, 1802.

Journals of the House of Lords: Volume 9 (1646) London: HMSO, 1767-1830. 
Bennett, Kirsty, ed. The Cardew Rendle Roll. London: Honourable Artillery Company, 2013.

Cerasano, S.P. and Wynne-Davies, Marion, eds. Renaissance Drama by Women: Texts and Documents. Abingdon: Routledge, 1996.

Jeaffreson, J.C., ed. Middlesex County Records, vol. 3. London: Middlesex County Record Society, 1888.

Raikes, G.A., ed. The Ancient Vellum Book of the Honourable Artillery Company Being a Roll of Members from 1611-1682. London: Richard Bentley and Son, 1890.

Shirley, James. The lady of pleasure, edited by R. Huebert, Manchester: Manchester University Press, 1986.

Spiers, Walter Lewis, ed. The Note-Book and Account Book of Nicholas Stone. Oxford: Walpole Society, vol.7, 1919.

\section{Secondary Bibliography}

Adamson, John. The Noble Revolt. London: Weidenfeld \& Nicolson, 2007.

Archer, Ian. The Pursuit of Stability: Social Relations in Elizabethan London. Cambridge: Cambridge University Press, 1991.

Ashton, Robert. The City and the Court, 1603-1643. Cambridge: Cambridge University Press, 1979.

Aylmer, Gerald. The King's Servants. The Civil Service of Charles I. London: Routledge \& Kegan Paul, 1961.

Barry, Jonathan. "Bourgeois Collectivism? Urban Association and the Middling Sort" in The Middling Sort of People. Culture, Society and Politics in England, 1550-1800, edited by Jonathan Barry and Christopher Brooks, 84-112. Basingstoke: Macmillan, 1994.

Braddick, Michael. State Formation in Early Modern England 1550-1700. Cambridge: Cambridge University Press, 2000.

Boynton, Lindsay. The Elizabethan Militia 1558-1638. London: Routledge, 1967.

Donagan, Donagan. "Halcyon Days and the Literature of War: England's Military Education Before 1642." Past \& Present, 147 (1995): 65-100.

Clark, Peter. British Clubs and Societies 1580-1800: The Origins of an Associational World. Oxford: Clarendon Press, 2000.

Cust, Richard. “Charles I's Noble Academy”, The Seventeenth Century, 29, no. 4 (2014): 337-357.

Geldof, Mark R. "The Pike and the Printing Press: Military Handbooks and the Gentrification of Early Modern Military Revolution" in International Exchange in the Early Modern Book World, edited by in Mathew McLean and Sara K. Barker, 147-168. Leiden: Brill, 2016.

Gregg, Pauline. King Charles I. London: J.M. Dent and Sons, 1981.

Hibbard, C.M. Charles I and the Popish Plot. Chapel Hill: University of North Caroline Press, 1983.

The History of the King's Works 1485-1660. Vol 3. Part 1, edited by Howard Colvin, David Ransome and John Summerson. London: HMSO, 1975.

The House of Commons 1604-1629, edited by Andrew Thrush and John Ferris. Cambridge: Cambridge University Press, 2010. 
Hunt, William. "Civic Chivalry and the English Civil War" in The Transmission of Culture in Early Modern Europe, edited by Anthony Grafton and Ann Blair, 204-237. Philadelphia: University of Pennsylvania Press, 1990.

Keen, Maurice. Chivalry. New Haven: Yale University Press. 1984

Kilburn-Toppin, Jasmine. "'Discords have arisen and brotherly love decreased': the spatial and material contexts of the guild feast in early modern London." Brewery History, 150 (2013): 28-38.

Kingsford, C.L. The Early History of Piccadilly, Leicester Square and Soho. (Cambridge: Cambridge University Press, 1925.

Lawrence, David. The Complete Soldier: Military Books and Military Culture in Early Stuart England 1603-1645. Brill: Leiden, 2009.

Manning, Robert. An Apprenticeship in Arms: The Origins of the British Army 1585-1702. Oxford: Oxford University Press, 2006.

Merritt, J.F. The Social World of Early Modern Westminster: Abbey, Court and Community 15251625. Manchester: Manchester University Press, 2005.

Merritt, J.F. Westminster 1640-60: A Royal City in a Time of Revolution. Manchester: Manchester University Press, 2013.

Merritt, J.F. "'Voluntary Bounty and Devotion to the Service of God'? Lay Patronage, Protest and the Creation of the Parish of St Paul Covent Garden, 1629-41." English Historical Review 125, no. 12 (2010): 35-59.

Mulryne, J. R. "'Here's Unfortunate Revels": War and Chivalry in Plays and Shows at the Time of Prince Henry" in War, Literature, and the Arts in Sixteenth-Century Europe edited by J.R. Mulryne and Margaret Shewring, 165-189. Basingstoke: Macmillan, 1989.

Oxford Dictionary of National Biography. Oxford: Oxford University Press, 2004.

Pearl, Valerie. London and the Outbreak of the Puritan Revolution. Oxford: Oxford University Press, 1961.

Pearson, David. "The English Private Library in the Seventeenth Century." The Library, 13, no. 4 (2012): 379-399.

Pitman, W. Hayward. The Worshipful Company of the Painters, Otherwise Painter-Stainers. London: privately printed, 1906).

Prak, Maarten, "Citizens, Soldiers and Civic Militias in Late Medieval and Early Modern Europe." Past \& Present, no. 228 (2015): 93-123.

Questier, Michael. Dynastic Politics and the British Reformations, 1558-1630. Oxford: Oxford University Press, 2019.

Raikes, G.A. The History of the Honourable Artillery Company, 2 vols. London: Richard Bentley \& Son, 1879.

Randall, Dale B.J. Winter Fruit. Lexington: University of Kentucky Press, 1995.

Sharpe, Kevin. The Personal Rule of Charles I. New Haven: Yale University Press, 1992.

Sherlock, Peter. "Militant Masculinity and the Monuments of Westminster Abbey" in Governing Masculinities in the Early Modern Period edited by Susan Broomhall and Jacqueline Van Gent, 131152. Aldershot: Ashgate, 2011. 
Survey of London, vol.20: St Martin in the Fields, pt. III. London: London County Council, 1940.

Survey of London, vol. 27: Spitalfields and Mile End New Town. London: Athlone Press, 1957.

Survey of London, vol. 36: Covent Garden. London: Athlone Press, 1970.

Survey of London, vol.34: St Anne Soho. London: Athlone Press, 1966.

Tittler, Robert. Townspeople and Nation: English Urban Experiences 1540-1640. Palo Alto: Stanford University Press, 2001.

Withington, Philip. "Citizens, Soldiers and Urban Culture in Restoration England." English Historical Review, 123, no. 502 (2008): 587-610.

Withington, Philip. Society in Early Modern England. Cambridge: Cambridge University Press, 2010. 